\title{
防潮堤と海岸林の位置関係が段波津波の流況と 海岸林に作用する流体力に与える影響
}

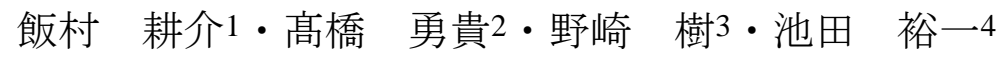 \\ 1正会員 宇都宮大学助教 地域デザイン科学部社会基盤デザイン学科 \\ （†321-8585栃木県宇都宮市陽東7-1-2） \\ E-mail: k_iimura@cc.utsunomiya-u.ac.jp \\ 2学生会員 宇都宮大学大学院工学研究科（干321-8585栃木県宇都宮市陽東7-1-2) \\ 3 (独) 鉄道建設・運輸施設整備支援機構（干231-8315 神奈川県横浜市中区本町6-50-1） \\ 4正会員 宇都宮大学教授 地域デザイン科学部社会基盤デザイン学科 \\ （†321-8585栃木県宇都宮市陽東7-1-2） \\ E-mail: ikeda@cc.utsunomiya-u.ac.jp
}

\begin{abstract}
巨大津波対策を考えるうえで, 複数の構造物を組み合わせて配置し, 減勢を図ることは非常に重要とな る. 本研究では, 防潮堤と海岸林による多重防護に着目し, 2 つの位置関係が構造物周辺の流況や海岸林 の流体力に与える影響について段波津波を用いた水理模型実験により検討した. 実験では水位, 対策構造 物周辺の流速, 海岸林への作用力, 遡上高をそれぞれ測定した.

防潮堤よりも海岸林を上流側に配置し，2つの対策構造物を隣接させるよりも距離を離す（本実験では $50 \mathrm{~cm}$ ) ことで海岸林への作用力を大きくし, 防潮堤を越流する流れを抑えることができる. また海岸林 への作用力が大きくなると, 作用反作用の関係から流れに対する抵抗としての働きが大きくなり, 模型背 後における遡上高を小さくすることができ, 減勢対策として効果的な配置方法であることが分かった。
\end{abstract}

Key Words : coastal forest, tsunami mitigation, tsunami flow pattern, fluid force acting on tree

\section{1. はじめに}

海岸林は津波に対して流速や浸水深の軽減，漂流物の 捕捉などの効果を持つことが古くから知られており（首 藤，1985 ${ }^{1}$ ），特に2004年のインド洋大津波以降その効 果が再認識され，有力な津波対策の一つとして注目され ている213,4). 一方，関東・東北地方の太平洋沿岸地域に 甚大な被害を与えた2011年の東北地方太平洋沖地震津波 のような巨大な津波に対しては，防潮堤等で完全に防ぎ きることは困難であり，津波を段階的に減じていく減災 対策が必要となる. 数 10 年から百数 10 年に1回の頻度で 発生するL1津波に対する対策と，過去最大級の規模で 発生するL2津波に対する対策に分け，特にL2に対して は防潮堤のみによる『防災』ではなく，都市計画・土地 利用計画による多様な手法により『減災』を実現してい く方針となっている5). こういった減災を実現していく ために, 海岸林や砂丘なども津波の流体力の低減や, 到 達時間の遅延をさせるための対策の一部とし，その機能 を定量的に評価していくことが重要な課題となっている. 東北地方太平洋沖地震津波の調査については, 田中らの, や佐々木・田中8)が2011年4-5月に仙台平野の海岸林や家
屋，堤防の被災状況を18地域で調査し，同地域の津波痕 跡浸水深を計測した。この調查においては, 海岸堤防よ り海側に海岸林がある場合は樹木の幹が破断し流失した 例が多いものの, 逆の場合は堤防背後の洗掘域より陸側 の樹木は倒伏していたものの現場に留まっている事例が 多く見受けられたとされている. その一方，砂浜・砂 草・海岸林の連続性を考慮し, 海岸林よりも陸側に堤防 を引堤することを鹰める意見や，経済的な面で防潮堤を 整備することが困難な開発途上の国においては海岸林背 後の道路を盛土により嵩上げすることで減災効果を得る ことができるとされている9．土屋ら ${ }^{10}$ は消波工と防潮 林を組み合わせて配置したときに，消波工と防潮堤の距 離によって防潮堤前面・背後での水平波力が変化するこ とを示した．飯村ら 11) 12)は津波のピーク付近の流れを想 定した定常流下において，防潮堤と海岸林を組み合わせ て配置したときの構造物周辺の基本的な流況と海岸林に よるエネルギ一軽減効果, 海岸林一の作用力について示 している. しかし，実際の津波流れは非定常であり，構 造物による反射等の影響を受けた複雑な流れとなる. 非 定常流下において防潮堤と海岸林による多重防護に対し ての構造物周辺の詳細な流況や海岸林への作用力などの 
基本的な知見はまだ十分に得られていない.

本研究では，段波を用いた水理模型実験を行い，防潮 堤と海岸林の配置方法の違いによる構造物周辺の詳細な 流況と海岸林に作用する流体力への影響を明らかにする ことを目的とする.

\section{2. 実験概要}

\section{(1) 実験水路および実験模型}

実験水路は，側面から流れの様子が観しやすいように 透明な塩化ビニル板を用いて, 全長 $1000 \mathrm{~cm}$, 幅 $30 \mathrm{~cm}$, 深さ40 cmの水路を作製し，水路床を水平になるように 調整した. この水路に海岸林模型と防潮堤模型を配置し て実験を行った.

海岸林模型は，現地の1/100スケールの縮尺で作製し た. 対象とする海岸林の現地スケールの条件は, 田中ら 5)のクロマツに関する調査結果を参考に，胸高直径 $15 \mathrm{~cm}$, 海岸林密度 0.2 本 $/ \mathrm{m}^{2}$ とした.これらの現地スケールの值 に対して, 海岸林模型の縮尺が $1 / 100$ となるときに，首 藤1)の海岸林の規模を表すパラメータである式(1)に示す 植生厚みdnが同程度となるように模型における海岸林密 度を決定した。

$$
d n=d \gamma\left(1 \mathrm{~m} \times W_{v}\right)
$$

ここに，dは胸高直径， $\gamma$ は海岸林密度， $W_{v}$ は岸沖方向 の海岸林幅, 汀線方向には単位幅（1 m) をとっている. 対象とした現地スケールにおける植生の厚み $d n$ は, 岸沖 方向の海岸林幅を200 mとしたときに600 本・ cmとなる. この值を参考に作製した海岸林模型では，海岸林は円柱 状のアクリル棒でモデル化し, 直径 $0.2 \mathrm{~cm}$, 海岸林密度 1372 本 $/ \mathrm{m}^{2}$ で正方形状に配置した。このときの模型にお ける植生の厚み $d n$ が549本・cmとなり, 現地スケールと の差が1割となっている.

防潮堤模型も海岸林模型と同様に縮尺が $1 / 100$ となる ように考え，天端高 $H$ を $3 \mathrm{~cm}$ とし，天端幅を $3 \mathrm{~cm}$ ，底面 幅 $W_{e b}$ を $15 \mathrm{~cm}$ (防潮堤法面の勾配を $\left.1 / 2\right)$ として塩化ビニ ル板を用いて作製した。

\section{（2）実験方法および実験条件}

表-1に水路および造波条件を示す．本実験ではゲート の上流側に水深が $15 \mathrm{~cm}$ となるように水をため，ゲート を急開させて段波を発生させた。防潮堤および海岸林模 型をどちらとも配置しない状態での波形を図-1に示す.

ゲートの急開は手動で行っているが，3回同じ条件で造 波し，入射波の再現性を確認した. 入射波は現地換算で 波の高さ $5 \mathrm{~m}$, 防潮堤を越流する時間はフルード相似で 考えると約3分となっている. 2011年津波の岩手県南部 沖における観測波形では，波の高さが約6.5 mで，約4分
表-1 水路および造波条件

\begin{tabular}{c|c}
\hline 水路の全長 & $1000 \mathrm{~cm}$ \\
水路床勾配 & 水平 \\
模型縮尺 & $1 / 100$ \\
造波方法 & ゲート急開 \\
ゲート上流側水深 & $15 \mathrm{~cm}$ \\
\hline
\end{tabular}

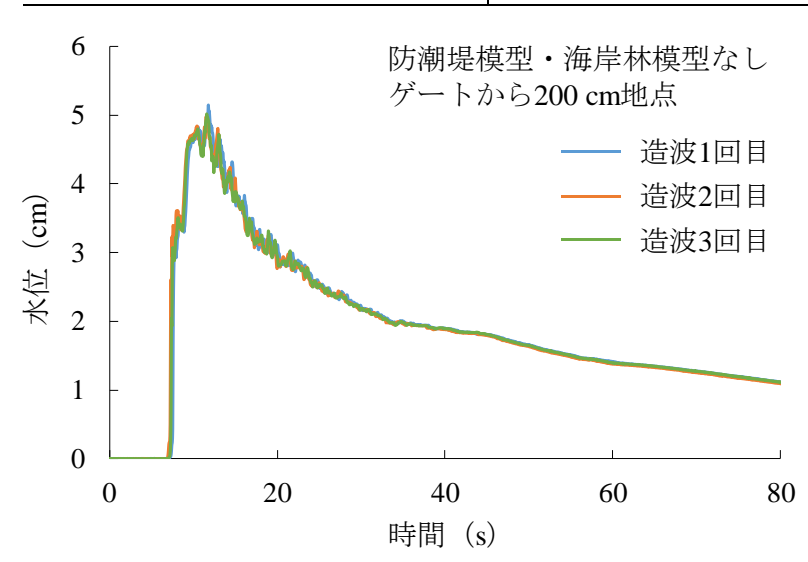

図-1 入射波の水位
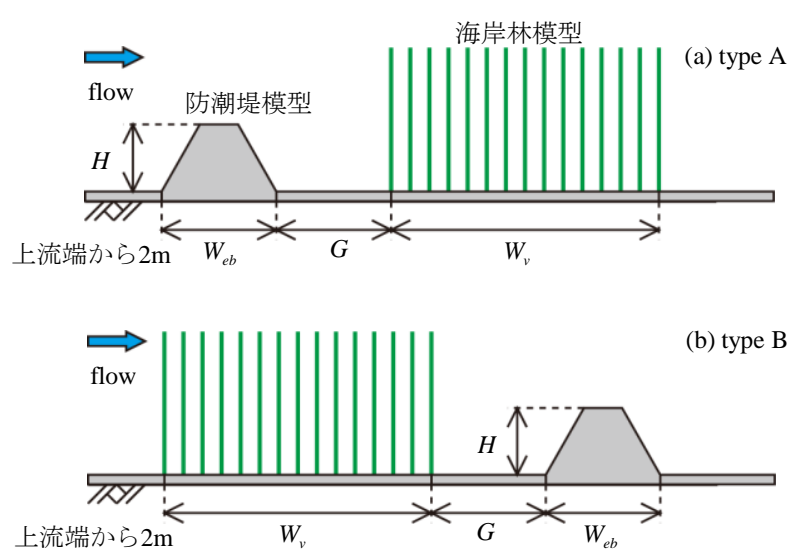

図-2 実験模型の配置方法

表-2 実験ケース一覧

\begin{tabular}{c|c|c|c|c}
\hline Caseno. & $\begin{array}{c}\text { 配置方法 } \\
\text { (図-1) }\end{array}$ & $\begin{array}{c}G \\
(\mathrm{~cm})\end{array}$ & $\begin{array}{c}H \\
(\mathrm{~cm})\end{array}$ & $\begin{array}{c}W_{v} \\
(\mathrm{~cm})\end{array}$ \\
\hline Case-A1 & typeA & 0 & & \\
Case-A2 & 50 & \multirow{2}{*}{3} & 200 \\
Case-B1 & typeB & 50 & & \\
Case-B2 & & 50 & & \\
\hline
\end{tabular}

間に $4 \mathrm{~m}$ 水位が急激に上昇する波形を示している5).

また，海岸林模型と防潮堤模型の配置方法と実験ケ一 スを図-2，表-2にそれぞれ示す，海岸林模型と防潮堤模 型の配置方法は配置typeをAとBの2つに分け，それぞれ， 
type Aは防潮堤模型を海岸林模型の上流側に配置, type B は防潮堤模型を海岸林模型の下流側に配置としている. それぞれの配置typeに対して，防潮堤・海岸林間距離 $G$ は模型を隣接させたケース $(G=0 \mathrm{~cm})$ と離したケース $(G=50 \mathrm{~cm})$ に対して実験を行った.

測定項目については，水位はサーボ式水位計を用いて 水路横断方向の中心点で，流速はPIVシステムを用いて 構造物模型周辺で，海岸林模型に作用する力は二成分型 分力計を用いてそれぞれ測定した. また，水路下流端に 勾配1/10の斜面模型を配置し，斜面上を遡上する段波の 遡上高を測定した.

\section{3. 実験結果および考察}

\section{(1) 水位の測定結果と考察}

水位は水路横断方向の中心線上で測定した. サンプリ ングレートは $20 \mathrm{~Hz}$ ，測定時間は120秒とした.

図-3にCase-A1およびCase-B1における最高水位，図-4 にCase-A2およびCase-B2における最高水位の空間分布を それぞれ示す. 配置 type Aでは上流側にある防潮堤が流 れを堰き止めることで水位が大きく上昇し，防潮堤越流 時に水位が減少するものの，下流側にある海岸林の堰き 止め効果もあり, 防潮堤越流時の水位減少は配置type B

(a) Case-A1

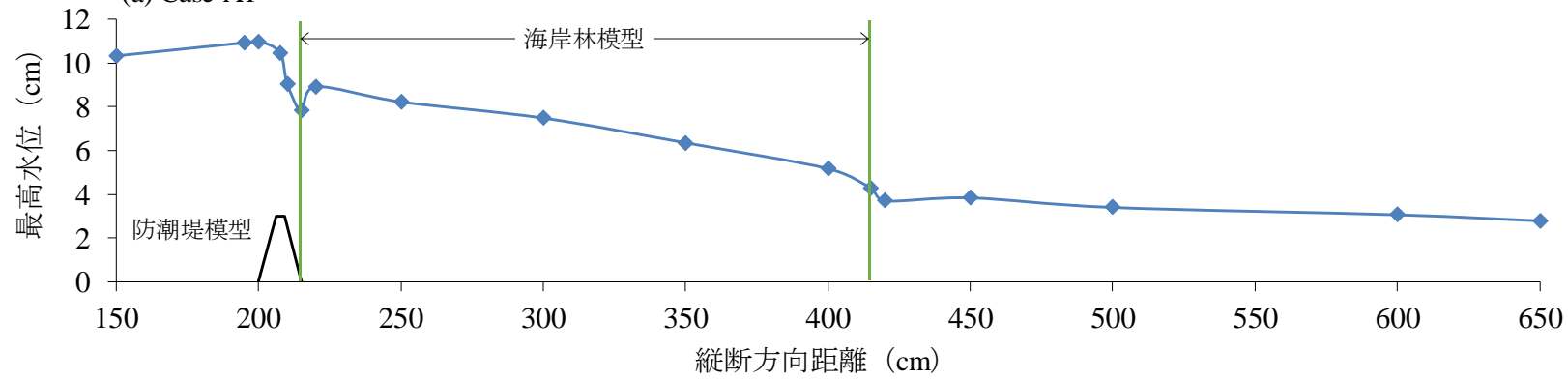

(b) Case-B1

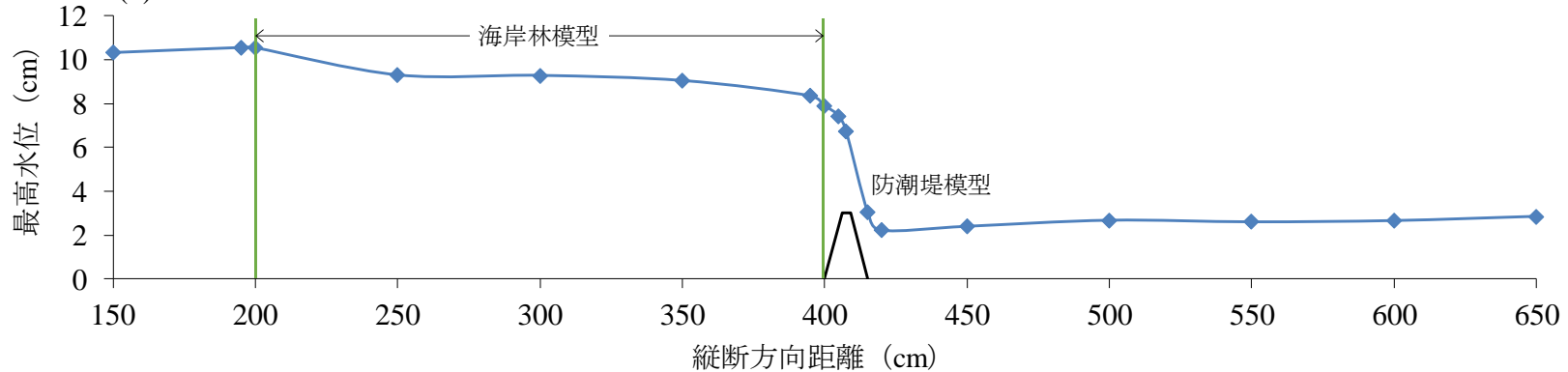

図-3 Case-A1 およびCase-B1 における最高水位 $(G=0 \mathrm{~cm})$

(a) Case-A2

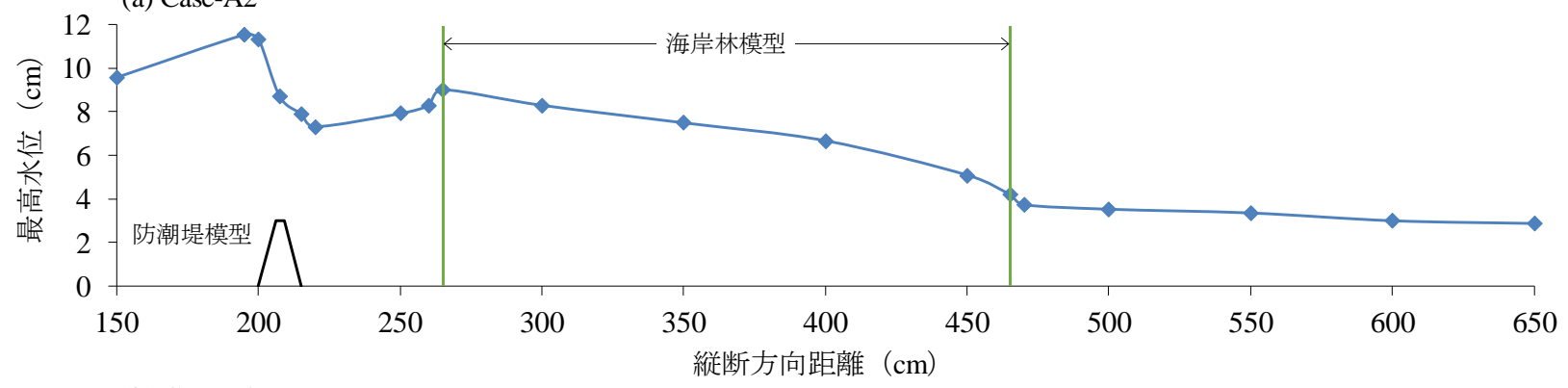

(b) Case-B2

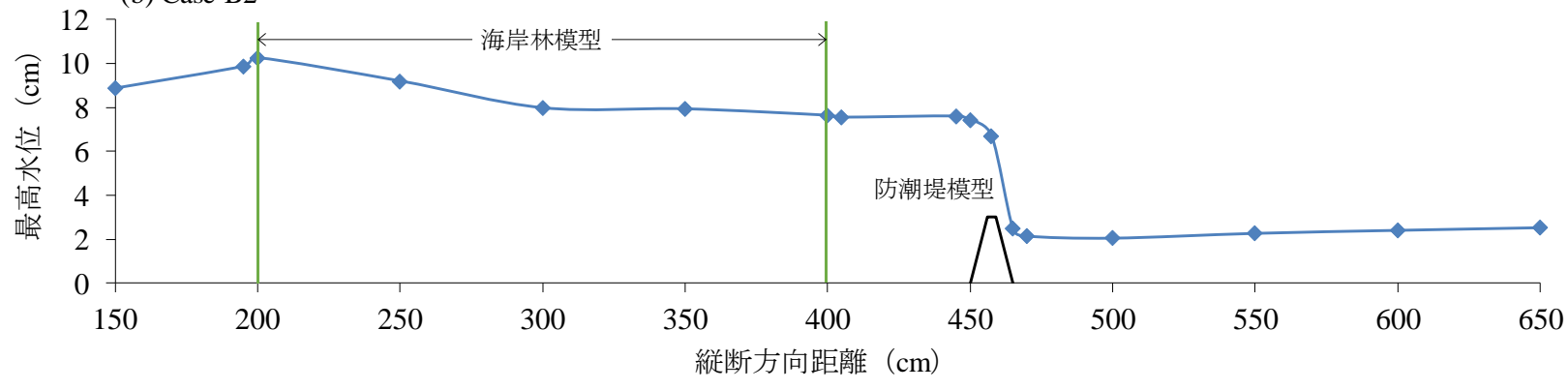

図-4 Case-A2 およびCase-B2 における最高水位（ $G=50 \mathrm{~cm})$ 
に比べて小さい. また，防潮堤越流後では海岸林の内部 で大きく水位が低減していく，模型間距離を離した条件 では，防潮堤越流時の水位減少は大きくなるが，海岸林 内部の水位減少や模型背後の水位には大きな影響は見ら れない. 配置type Bにおいては，上流側にある海岸林に よる流れの堰き止め効果により海岸林前面で水位が大き く上昇する. 一方で, 海岸林内部での水位減少は海岸林 背後の防潮堤による堰き止め効果により小さくなってい るが，防潮堤越流前後の水位の変化はtype Aに比べて大 きくなっている. 全模型背後（縦断方向距離650 cm地点） における水位が最も小さくなるのはCase-B2であった. また模型間の距離を離すと, 上流側の海岸林に対する背
後の防潮堤による流れの堰き止め効果の影響が小さくな り, 海岸林内部の水位減少が $G=0 \mathrm{~cm}$ に比べて大きくな る.

\section{(2) 流速の測定結果と考察}

PIVによる流速測定では水路側壁から $15 \mathrm{~cm}$ 離れた鉛直 断面（横断方向の中心線上）をレーザーライトシートに より可視化し，水路の側方から高速度カメラで撮影した。 本実験では，Photron製の高速度カメラ（FASTCAM： SA3）とDantec Dynamics製の解析ソフト (DynamicStudio) を使用し，撮影範囲は約 $12 \mathrm{~cm} \times 12 \mathrm{~cm}$ で，フレームレー トは500 fps，シャッタースピードは1/500秒，撮影時間は
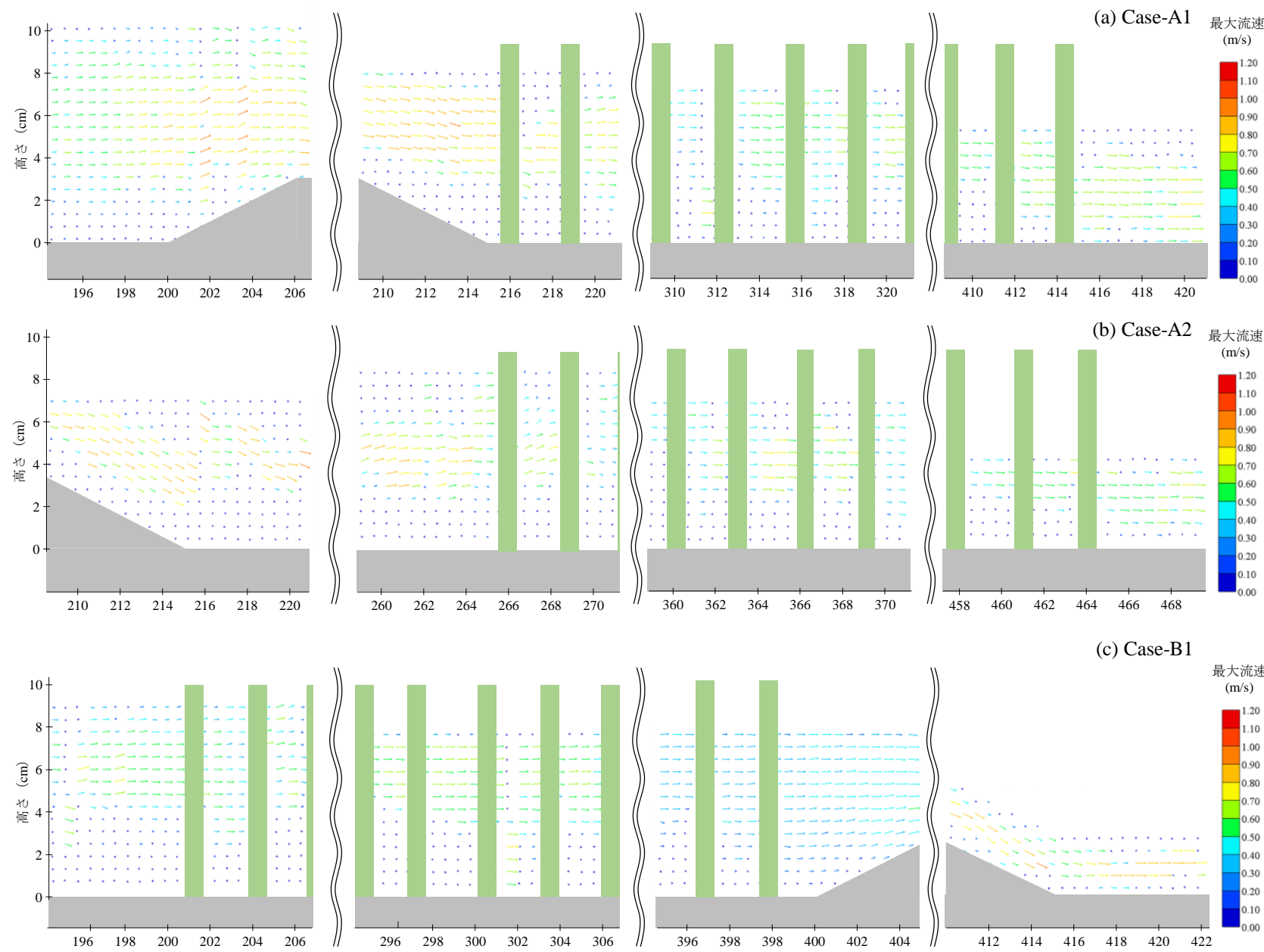

(c) Case-B1
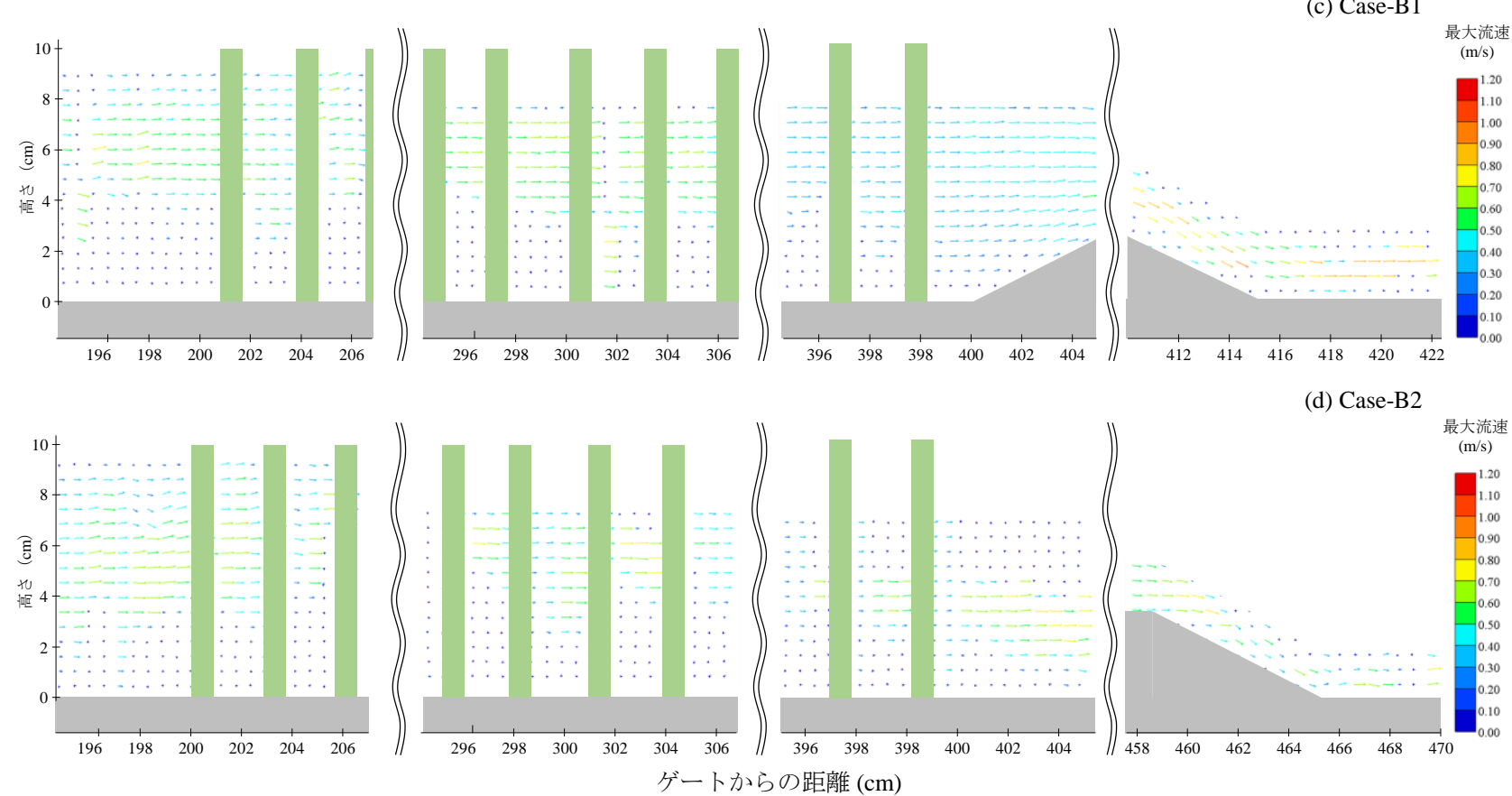

(d) Case-B2

図-5 津波進行方向の最大流速の空間分布 
約15秒で計測した.

流速については，本研究では流れによる流体力に着目 し，式(2)で計算される流体力指標 $F か ゙$ 最大となるときの 流速分布を配置typeごとにまとめた（図-5) .

$$
F=\int_{0}^{h} u^{2} d z
$$

ここに，hは水深，uはx方向（津波進行方向）流速， $z$ は 鉛直方向軸である.海岸林が防潮堤よりも下流側にある type Aでは防潮堤に近づくにつれて流れが加速し, 加速 した速い流れが防潮堤越流後の海岸林にぶつかっている ことが見てとれる。防潮堤と海岸林の距離が近い場合

（Case-A1）は，海岸林前面で流れが堰き上げられるた め，鉛直方向の上層に流れの速い領域が確認できる。一 方，防潮堤と海岸林の距離が離れると（Case-A2），模 型間の領域で徐々に鉛直方向に一様な流れに遷移し, 海 岸林前面でもほぼ一様な流れとしてぶつかっている. ま た, 海岸林を通過した後の模型の背後では海岸林による 抵抗がなくなるため, 海岸林の内部に比へてて流速が若干 大きくなっている，海岸林が防潮堤よりも上流側にある type Bでは, 海岸林に接近する流れも, 海岸林の内部の 流れも鉛直方向にほぼ一様な流れとなっている．また海 岸林を通過する過程で, 海岸林の抵抗により徐々に流れ が減速している. その後, 海岸林の外に出た直後や防潮 堤を流れおちる箇所で流れが加速しているが, type Aと 比べると浸水深が小さいこともあり, 加速後の流速の大 きさも, 流速の速い領域の大きさもtype Aに比べて小さ い. 特に $G=0 \mathrm{~cm}$ の時は, 海岸林下流側の流れに背後の 防潮堤による堰き止め・反射の影響あり, 流速が他のケ 一スと比べて小さくなっていることが確認できる.

\section{(3) 海岸林に作用する流体力の測定結果と考察}

海岸林模型への作用力の測定は二成分型分力計（SSK 製，LB60-1N）を用いて水路横断方向中央の列に対して, 流下方向に $25 \mathrm{~cm}$ 間隔で測定した。 なお，測定の際のサ ンプリングレートは $100 \mathrm{~Hz}$ ，測定時間は60秒とした.

海岸林 1 本あたりに作用寸る力について, その最大值 を模型間距離 $G=0 \mathrm{~cm}, G=50 \mathrm{~cm}$ についてそれぞれ図-6,

図-7に示寸．また比較対象として，防潮堤模型を配置せ ず，海岸林模型のみを配置したときの最大作用力につい ても示す. 配置type Bでは, 防潮堤よりも海岸林が上流 側にあり，津波の流れはまず海岸林に作用するため海岸 林の夕を配置した場合と同じような作用力の分布となる。 海岸林のみの場合と比較して, Case-B1では平均10\%, Case-B2では平均8\%の差が見られた. また $G=0 \mathrm{~cm}$ の時で は流速分布と同様に海岸林の下流側では, 背後の防潮堤 からの堰き止め・反射の影響で流速が下がるため, 海岸 林の夕を配置した条件と比べて作用力が最大 $42 \%$ 小さく なっている.一方， $G=50 \mathrm{~cm}$ では模型同士が離れ，防潮

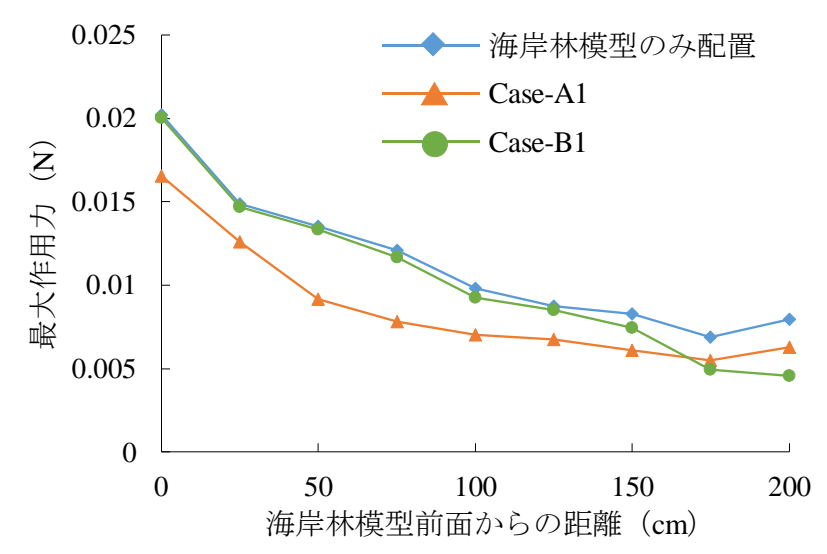

図-6 海岸林模型への最大作用力 $(G=0 \mathrm{~cm})$

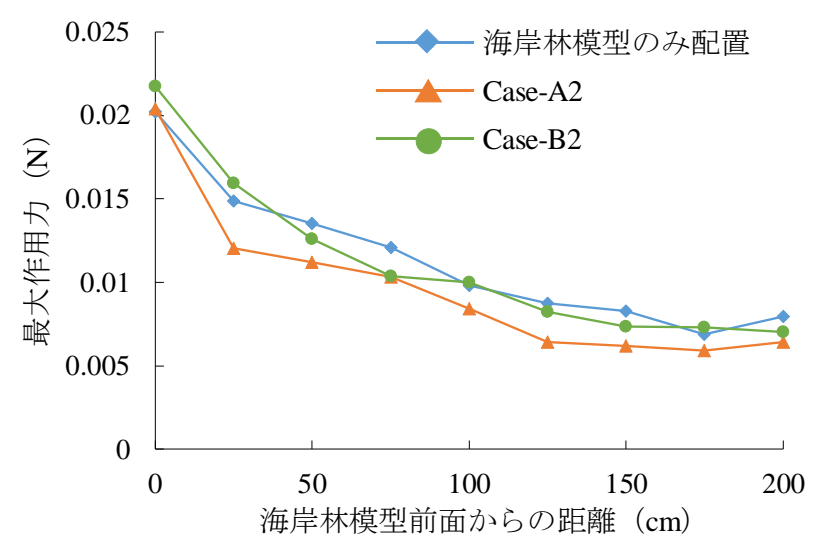

図-7 海岸林模型への最大作用力 $(G=50 \mathrm{~cm})$

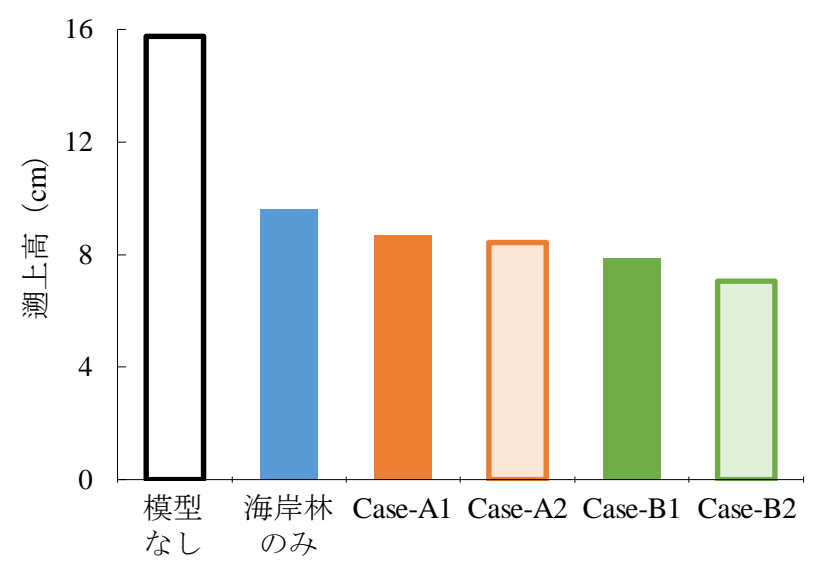

図-8 各ケースにおける遡上高

堤の海岸林一の影響が弱まるため，海岸林の下流側では， 海岸林のみを配置した条件との差が最大 $11 \%$ とさくな った. 配置type Aでは防潮堤越流後の流れが海岸林に作 用する. 越流時に流れは加速するものの浸水深は小さく なり，防潮堤が津波を反射する影響もあり，全体的に海 岸林一の作用力は他のケースに比べて小さくなっている. 海岸林のみの場合と比較して, Case-A1では平均 $24 \%$, Case-A2では平均16\%の差が見られた。防潮堤と海岸林の 距離が近いケースと離れたケースを比較すると, type A では，Case-B1のような海岸林下流側に見られた局所的 な大きな差は見られず，平均して $12 \% の$ 差が見られた. 


\section{(4) 遡上高の測定結果と考察}

遡上高は水路下流端に勾配1/10の斜面模型を設置し, 遡上の様子をビデオカメラで撮影し，撮影した動画から 遡上距離を求め，遡上高を算出した，遡上高は各ケース 3 回測定し，その平均值をとっている. 図-8に各実験ケ 一スにおける遡上高を示寸，比較対象として，海岸林お よび防潮堤をどちらも配置しない”模型なし”と，“海岸 林のみ”配置したケースを示す。模型を配置したケース では，模型なしに比べて遡上高はおおよそ半分程度とな っている. 最も遡上高が小さくなったのはCase-B2で, 海岸林一の作用力が大きく，また防潮堤が海岸林の背後 にあり，海岸林によって減勢された津波が防潮堤にあた るため, 遡上高の軽減効果が大きくなったと考えられる.

\section{4. おわりに}

防潮堤と海岸林の位置関係が，流況や海岸林の流体力 に与える影響について水理模型実験により検討した。防 潮堤よりも海岸林を上流側に配置し， 2 つの距離を適切 に離すことで海岸林一の作用力を大きくし，防潮堤を越 流する流れを抑えることができる，その結果，遡上高を 小さくすることができ，減勢対策として効果的な配置方 法であることが分かった。

謝辞 : 本研究は, 日本学術振興会の科学研究費補助金 (若手研究（B）16K16373）の支援により実施されまし た。ここに記して謝意を表します。

\section{参考文献}

1) 首藤伸夫: 防潮林の津波に対する効果と限界, 第 32 回 海岸工学講演会論文集, pp.465-469, 1985.

2) 谷本勝利, 田中規夫, N.A.K. Nandasena, 飯村耕介, 清水 隆: 種々の熱帯性海岸樹の組合せによる津波防御効果 に関する数值計算, 海岸工学論文集, Vol. 54, pp.1381-
1385, 2007.

3) Tanaka, N., Sasaki, Y., Mowjood, M. I. M. and Jinadasa, K. B. S. N. : Coastal vegetation structures and their functions in tsunami protection: Experience of the recent Indian Ocean tsunami, Landscape and Ecological Engineering, Vol.3, pp.33-45, 2007.

4) Mascarenhas, A. and Jayakumar, S. : An environmental perspective of the post-tsunami scenario along the coast of Tamil Nadu, India: Role of sand dunes and forests, Journal of Environmental Management, Vol.89, pp.24-34, 2008.

5）（独）港湾空港技術研究所：2011 年東日本大震災によ る港湾・海岸・空港の地震・津波被害に関する調査 速報, 港湾空港技術研究所資料 No.1231, 173p, 2011.

6) 田中規夫, 安田智史, 八木澤順治: 津波時における海岸 林の家屋被害軽減量の定量化, 京都大学防災研究所東 日本大震災特別緊急共同研究報告会, 京都大学, pp.2938,2012

7) 田中規夫, 八木澤順治, 飯村耕介, 近藤康太: 津波によ る海岸林および流失家屋が家屋被害に与えた影響, 土 木学会論文集 B2（海岸工学）, Vol.68, No.2, pp.I_301I_305, 2012.

8）佐々木寧, 田中規夫: 東北地方太平洋沖地震における 津波被害と海岸林の状況～仙台平野（福島県、宮城 県）における海岸林被害状況調査結果〜, 植生学会 (http://shokusei.jp/_userdata/Disaster_area_status2.pdf) 2011.

9) 佐々木寧, 田中規夫, 坂本知己: 津波と海岸林 バイオ シールドの減災効果, pp.181-203, 共立出版, 2013.

10) 土屋十图, 吉江悟: 津波に対する防潮林の保全と消波 工の連携型水理実験, 第 67 回土木学会年次学術講演 会講演概要集, II -214, pp.427-428, 2012.

11）飯村耕介, 池田裕一, 内海翔太, 青木貴志: 海岸林と防 潮堤の位置関係が周辺流況と減勢効果に及ぼす影響 に関する実験的研究，土木学会論文集 B3（海洋開 発）, Vol. 71, No. 2, pp. I_629-I_634, 2015.

12）飯村耕介, 野崎樹, 高橋勇貴, 池田裕一: 津波の流況之 海岸林の抵抗力に防潮堤と海岸林の位置関係が与え る影響に関する実験的研究, 土木学会論文集 B3（海 洋開発）, Vol. 73, No. 2, 2017。（掲載予定）

(2017.3.15 受付)

\title{
EFFECT OF A COMBINED POSITION OF COASTAL FOREST AND EMBANKMENT ON TSUNAMI FLOW PATTERN AND FLUID FORCE ACTING ON TREES
}

\author{
Kosuke IIMURA, Yuki TAKAHASHI, Tatsuki NOZAKI and Hirokazu IKEDA
}

For tsunami mitigation, suitable arrangement of multiple tsunami measure structures is very important. The objective of this study is to estimate effect of a combined position of coastal forest and embankment on tsunami flow pattern and fluid force acting on tree by the hydraulic model experiment.

When the coastal embankment is in the lower stream side of the coastal forest, the fluid force acting on trees becomes large, and the coastal forest is expected as resistance to tsunami. And tsunami mitigation effect becomes most significant (i.e. runnp height becomes most smallest) when the embankment is in the lower stream side of the coastal forest. 